\title{
Nigerian Cassava Potentials in National Economic Development
}

\author{
Nnadozie A. K. O. ${ }^{1,}$, , Ume S. I. ${ }^{2}$ Isiocha S. ${ }^{3}$, Njoku I. A. ${ }^{1}$ \\ ${ }^{1}$ Department of Marketing, Federal College of Agriculture, Ishiagu, Nigeria \\ ${ }^{2}$ Department of Agricultural Extension \& Management, Federal College of Agriculture, Ishiagu, Nigeria \\ ${ }^{3}$ Department of Home \& Rural Economics, Federal College of Agriculture, Ishiagu, Nigeria
}

\section{Email address:}

akonnadozie@yahoo.com (Nnadozie A. K. O.), goodynjoku@yahoo.com (Njoku I. A.), umesmilesi@gmail.com (Ume S. I.), stellaisiocha@yahoo.com (Isiocha S.)

\section{To cite this article:}

Nnadozie A. K. O., Ume S. I., Isiocha S., Njoku I. A. Nigerian Cassava Potentials in National Economic Development. Science Journal of Business and Management. Special Issue: Sustainable Entrepreneurial Developments in Agribusiness. Vol. 3, No. 5-1, 2015, pp. 47-49. doi: $10.11648 /$ j.sjbm.s.2015030501.20

\begin{abstract}
Cassava had been a utility crop with diverse food provision and high yielding potentials. Apart from serving as food for human consumption, it has numerous industrial uses like chips, flour, starch and the leaves which have a high export demand. Nigeria's comparative advantage in production has made it have a very high potential in face of the dwindling World oil prices. Nigeria cassava production has been with an annual output of over 38 million tons of tubers and was adjudged as one of the largest producers of cassava in the world. Total area harvested in 2009 alone was estimated to be 3.13 million hectares, with an average yield of 11.7 tons/ha-1. Its high employment income generation and 20 percent cassava flour inclusion in bread made it a crop to be harnessed and fully utilized to raise economic development in Nigeria.
\end{abstract}

Keywords: Cassava Potentials, Non-Oil Export, Raw Materials, Job/Wealth Creation, Economic Development

\section{Introduction}

This paper is a review of the economic potentials of cassava in Nigeria. Nigeria is currently the largest producer of cassava in the world with an annual output of over 38million tones of tubers (FAO STAT, 2010). Nigerian cassava production is by far larger than production in Brazil and almost double the production of Indonesia and Thailand. Cassava production in other African countries, the Democratic republic of Congo, Ghana, Madagascar, Mozambique, Tanzania and Uganda are small in comparison to Nigeria's substantial output (NON, 2014).

There are numerous industrial uses of the crop such as cassava chips, flour, starch, and cassava leaves which all have high export demand. The Nigeria's comparative advantage in production of cassava are favourable factors. Cassava can be substituted as feed ingredient for corn and other grains without any negative effect on poultry and piggery.

The $20 \%$ cassava flour success in bread and bakery sectors of Nigeria under the ATA- Agricultural Transformation Agenda of the Federal Government of Nigeria has created a new wave. Despite the fact that many Nigerian women process cassava for a living, the new window of opportunities for export of cassava products have heightened cassava potentials in the national economy.

The Agricultural Development programme (ADPs) is probably one of the boldest attempt by the Federal Government of Nigeria to pursue an integrated rural development on relatively long term basis (Eboh et al., 1995). The system is based on the premise that only combined efforts applied almost simultaneously can reduce the problems of low farmers' productivity, income and provide over 90 percent of gross Domestic food supplies ( Akubiulo, 2008).

Cassava is one major root crops in Nigeria and with the presidential initiative on cassava in 2002 (Ezechinma,2006) and the Agricultural Transformation Agenda of the government in 2012, there has been an increased awareness and demand for the crop. In 2005, Nigeria was the largest producer of cassava in the world with 38 million metric tons. This represents an increase of $100 \%$ from the 1990 production of 19 million metric tons (FAO, 2006). Cassava's ability to produce food under marginal conditions has made it a popular crop of Africa's poor resource farmers who are 
unable to invest in fertilizer or pesticides.

There has not been enough awareness and publicity on the current potentials of Nigerian cassava as a dollar magnet crop with ability to upturn petro-naira revenue. Total area harvested in 2009 was estimated to be 3.13 million hectares, with an average yield of 11.7 tons $/ \mathrm{ha}^{-1}$ produced predominantly $(99 \%)$ by smallholder farmers with $1-5$ ha of land intercropped with yams, maize, or legumes in the rainforest and savannah agro-ecologies of southern, central, and lately Northern Nigeria. An increase in the production and market demand has spun an entire food industry and transformed the crop from a rural subsistence crop to foreign exchange earner and urban food staple (FAOSTAT,2010). This increased eminence of cassava potentials in Nigerian economy needs guided study for empirical evidence to show the hidden revenue and job creation opportunities in "Nigeria cassava wonder crop".

Empirical evidence of cassava potentials in Nigeria

Now, consumers find it difficult to differentiate cassava bread from other common varieties, except value for money implies that investing in cassava production could provide a range of developmental benefits to Nigerian economy. Banking on this positive consumer response is a high -stake bet that could transform the lives of millions of Nigerians. FAOSTAT (2010) stated that cassava is the main source of calories for 500 million people, mostly in tropical or subtropical regions.

Nwosu (2005) stated that cassava is drought resistant and available year round, offering at least some cushion against food shortages. Nearly $90 \%$ of cassava in Nigeria is grown by smallholder farmers. The way forward therefore, is breeding more nutritional varieties adapted to local conditions and increasing pest/disease resistance which will be of greater advantage to Nigerian smallholder farmers. Social indicators reflect the real distortions of what many Nigerians call the curse of oil but cassava export can effectively increase our revenue from the non-oil sector.

World Development Index (WDI, 2013) reported that over $90 \%$ of Nigerians lived on less than US 2 Dollars daily. Nigeria is 169 out of 179 countries rated on the well-being of mothers. One in six children dies before their fifth birthday. These were the woes of the 1970s oil exploration in Nigeria abandoned investment in almost every sector except petroleum by the successive authoritarian governments before 1999. Thus, Nigeria's schools, rural infrastructures and agriculture deteriorated. Ironically, forcing critics to term Nigeria's oil boom as oil doom! However, in the face of the current World oil price decline, cassava export can do Nigeria a favour in increasing her foreign exchange earnings.

\section{Nigeria Food Production Potentials}

Nigeria that once exported food crops- controlling about $42 \%$ of global groundnut and oil-palm products trade, now spends US 11 billion Dollars yearly on food importation with about US 4 million Dollars on wheat. The new emerging fact is that cassava exports have the potentials of re-writing these ugly stories for better perspective. Cassava stories are more pervasive for the following variables:

i. An increase in income of 1.8 million smallholder farmers by US450 dollars yearly.

ii. The generation of 1,000000 jobs in rural Nigeria over the next 3 years.

iii. A strong value added chains of starch, high quality cassava flour-HQCF, sweeteners, dried chips, high quality garri, and fuel ethanol in Nigeria.

iv. Strong market agencies /institutions established for long term sustainability of the cassava sub-sector of Nigerian economy.

v. A doubling of average cassava yield from 12 tons to 25 tons/ha by use of improved, disease resistant and adapted cassava varieties from International Institute for Tropical Agriculture-IITA, National Root Crop Research Institute, Umudike -NRCRI and West African Agricultural Productivity Programme -WAAPP.

There is a potential demand of 250,000 tons/year in the high quality cassava flour, primarily from $20 \%$ replacement in bread flour and for use in bouillon, noodles , and the adhesive industry- dextrin; a demand equivalent of 1.2 million tons of fresh tubers. Similarly, demand for native and modified starches exceeds 230,000 tons annually in the food, paint and pharmaceutical industries, another one million tons of fresh tuber. The potentials of Nigerian cassava in the national economy is summed up in Table 1 below

Table 1. Nigerian cassava potentials in national Economy.

\begin{tabular}{|c|c|c|c|c|}
\hline Value added chain & Estimated demand & Fresh tuber eqvlent to meet estd. Dd mt. & Area $\mathbf{r q d} 25 \mathrm{t} / \mathrm{ha}$ & 2jobs/ha-1 on/off farm \\
\hline Starch & $230,000 \mathrm{mt}$ & $1,150,000$ & 46,000 & 92,000 \\
\hline Flour & $250,000 \mathrm{mt}$ & $1,000,000$ & 40,000 & 80,000 \\
\hline *sweeteners & $190,000 \mathrm{mt}$ & 950,000 & 38,000 & 76,000 \\
\hline Dried chips $^{\wedge}$ & $900,000 \mathrm{mt}$ & $3,360,000$ & 134,400 & 268,560 \\
\hline Fuel ethanol-E ${ }^{10}$ & 0.5 billion litres & $3,571,428$ & 142,857 & 285,714 \\
\hline $\begin{array}{l}\text { HQ Garri-export \& } \\
\text { Supermarkets }\end{array}$ & 455,000 tmt & $2,730,000$ & 109,200 & 218,400 \\
\hline Total & & $12,758,429$ & 510,337 & $1,020,674$ \\
\hline
\end{tabular}

*Assumes $50 \%$ replacement of imported sugar in the sweetener industry. ${ }^{\wedge}$ assumes $50 \%$ from cassava as feedstock. $\mathrm{E}^{10}$ assumes $10 \%$ cassava ethanol is mixed with gasoline under E 10 policy.

Sources: Adapted from Nigerian cassava processors \& marketers association (NICAPMA, 2014; WAAPP, 2014; NNPC, 2011; NBS2010; FAOSTAT, 2010).

In the sweetener industry, an annual demand of 150,000 tons exist for high fructose syrup. This is as part of 
replacement for imported sugar, and 40,000 tons/yearly for glucose $(40,000$ tons per annum) which requires an additional 950,000 tons of fresh tubers - Table 1 (FAOSTAT, 2010).

Nigerian National Petroleum Corporation (NNPC, 2011) stated that dried cassava chips value chain has a potential demand of $900,000 \mathrm{t} / \mathrm{yr}$. with $300,000 \mathrm{t} / \mathrm{year}$ going to the regional food market, an estimated $80,000 \mathrm{t} / \mathrm{yr}$. to the local animal feed market and 520,000 tons destined for the China export market thus the dried chips market requires 3.4 million $\mathrm{t} / \mathrm{yr}$. of fresh tubers. Nigeria E-10 policy which is blending of gasoline with $10 \%$ ethanol, a potential demand of 2.3 million tons of fresh tuber exists (Table 1).

An estimated 4.2 million tons of garri widely consumed by Nigerians were produced in 2009. The size of the high quality garri market is estimated empirically to be 455,000 tons yearly, 65,000 tons annually from export to the diaspora and $390,000 t / y r$. demand from supermarkets, equivalent to 2.73 million tons of fresh tubers annually. Statistically, Table 1 has shown that combined opportunities for cassava in the industrial, export and retail industries amount to 12.7 million tons of fresh tubers from 510,337ha of land which will generate more than one million jobs in rural Nigeria (NBS, 2010).

The cassava stem production enterprise, is an aspect of the new cassava potentials capable of increasing smallholder farmers' income and thereby, poverty reduction is achieved. It also has the ability to generate and add half a million jobs in Nigeria thus reducing unemployment rate. This will be due to increase in the demand for planting materials and since the enterprise lasts for a 3-month span, it will be replicated 3 times yearly and can generate up to N200 million for Nigerian rural farmers yearly(WAAP, 2014).

\section{Conclusion}

Based on the empirical evidence and analysis, the Nigerian cassava potentials in national economy will increase food security, reduce poverty and generate more jobs for youths in the country with increased foreign exchange earnings. The high economic potentials Nigerian cassava output if well utilized will prop up our ailing economy.

Therefore, there should be massive investment in the production of high yielding cassava in Nigeria by all and sundry. The corporate partners in the private and public sectors such as the Nigerian National Petroleum Corporation should invest significantly on research in collaboration with Nigerian universities and colleges to harness the cassava potentials to enhance smallholder farmers' productivity in Nigeria. The Central Bank of Nigeria relying on the ATAAgricultural Transformation Agenda should imbue farmers with access to funds from specialized banks for industrial growth and clusters of cassava sub-sector of Nigerian economy to capture its desired position as THE GAINT OF AFRICA!

\section{The Authors Affiliation}

1. Dr. Nnadozie A.K.O. is a lecturer and Head, Department of Marketing; Federal College of Agriculture, Ishiagu Nigeria.

2. Dr. Ume. S. I. is a lecturer and Head, Department of Agricultural Extension and Management, Federal College of Agriculture, Ishiagu Nigeria.

3. Isiocha S.C. is a lecturer and Head, Department of Home and Rural Economics, Federal College of Agriculture, Ishiagu Nigeria.

4. Mr. Njoku I.A. is a lecturer, Marketing Department, Federal College of Agriculture, Ishiagu Nigeria.

\section{References}

[1] Akubuilo, C.J.C (2008) the perception of ADP Extension Service delivery in Enugu State. Auto Century .Enugu Nigeria.

[2] Eboh, E.C; Okoye, C.U and Ayichi, D (1995) Rural Development in Nigeria. Concepts, principles and practices, Enugu, Auto Century.

[3] Ezedinmma, C.I (2003). Post-Harvest potential of Root and Tuber crops. Proceeding of $13^{\text {th }}$ Symposium of International Society for Tropical Root Crops; held in Arusha, Tanzania November 10-14.

[4] Ezedimma. C. and Asomugha C (2006). Trends in farm labour productivity and implications for cassava industrialization in Nigeria National Root Crops Research Institute, Umudike, Umuahia, Nigeria.

[5] FAO (2006). Food and Agricultural Organization .Data Basic Result

[6] FAO (2010). FAOSTAT, Statistical Division of the Food and Agricultural organization, Roman Italy. www.Faostat .org

[7] NBS (2010). Annual Report. National Bureau of Statistics, Abuja, Nig.

[8] NNPC (2011). Annual Report on Research Highlights. Nigerian National Petroleum Corporation. Abuja, Nigeria.

[9] Nigerian Orient News, 2014; http://www.nigerianorientnews.com/

[10] Nwosu K.I.O (2005). Problems and constraints in the production of Arable crops seed proceeding for meeting Raw materials requirement for the Existing and Emerging Industries. Invited paper presented at a two day tutorial consultative meeting on the proposed Establishment of the industrial Crop production and Advisory centers in the six Geo - political Zone. 16-17 August - NRCRI, Umudike, Abia State, Nigeria.

[11] WAAP (2014). Training Manual on Cassava Commercialization- Adding Value through Product Development: workshops held on May $28^{\text {th }} \& 30^{\text {th }}$ at Unity Secondary School \& Ishiagu High School, Ivo Local Government Area, and Ebonyi State, Nigeria. 